\title{
Determination of optimum levels of nitrogen, phosphorus and potassium of oil palm seedlings in solution culture
}

\author{
Hasmah Mohidin (1,4); Mohamed Musa Hanafi (1,2*); Yusop Mohd Rafii ( ${ }^{(1)}$; Siti Nor Akmar Abdullah ( $\left.{ }^{1}\right)$; \\ Abu Seman Idris ( $\left.{ }^{3}\right)$; Sulaiman Man $\left({ }^{4}\right)$; Juferi Idris $\left({ }^{5}\right)$; Mahbod Sahebi $\left({ }^{1}\right)$ \\ (') Universiti Putra Malaysia (UPM), Institute of Tropical Agriculture, Laboratory of Plantation Crops, \\ 43400 Serdang, Selangor, Malaysia. \\ (2) (UPM), Faculty of Agriculture, Department of Land Management, 43400 Serdang, Selangor, Malaysia. \\ (3) Malaysia Palm Oil Board (MPOB), GanoDROP Unit, Biological Research Division, No. 6, Persiaran Institusi, \\ Bandar Baru Bangi, 43000 Kajang, Selangor, Malaysia. \\ (4) Universiti Teknologi MARA (UiTM), Faculty of Agrotechnology and Plantation, 94300 Kota Samarahan, Malaysia. \\ (5) (UiTM), Faculty of Chemical Engineering, 94300 Kota Samarahan, Malaysia. \\ $\left(^{*}\right)$ Corresponding author: mmhanafi@agri.upm.edu.my
}

Received: Nov. 17, 2014; Accepted: Feb. 22, 2015

\begin{abstract}
Balanced nutrient elements in fertilizer play a critical role in oil palm seedling successful growth and development, and at the same time reduces of fertilizer losses in the environment. This study examines the effect of different levels of $\mathrm{N}, \mathrm{P}_{2} \mathrm{O}_{5}$ and $\mathrm{K}_{2} \mathrm{O}$ for oil palm seedlings in solution culture on growth traits, nutrient uptake in plant tissues and biomass accumulation under nursery conditions. Five concentration levels of $\mathrm{N}$ (50, 100, 300, 600 and $\left.900 \mathrm{mg} \mathrm{L}^{-1}\right), \mathrm{P}_{2} \mathrm{O}_{5}$ and $\mathrm{K}_{2} \mathrm{O}\left(15,30,60,90\right.$ and $120 \mathrm{mg} \mathrm{L}^{-1}$ ) were used in a completely randomized design (CRD) with five replications for each. Parameters measured during the growing period include - plant height, leaf number/plant, stem diameter, SPAD chlorophyll value, and at harvest - total leaf area, root dry weight, shoot dry weight and total dry weight. Different levels of $\mathrm{N}, \mathrm{P}_{2} \mathrm{O}_{5}$ and $\mathrm{K}_{2} \mathrm{O}$ showed significant effects on all the parameters studied. The highest values for diameter, plant height, leaf number/plant, total leaf area, root dry weight, shoot dry weight and total dry biomass were obtained using 100, 90 and $300 \mathrm{mg} / \mathrm{L}$ levels of $\mathrm{N}, \mathrm{P}_{2} \mathrm{O}_{5}$ and $\mathrm{K}_{2} \mathrm{O}$, respectively. Most of the growth parameters, declined with lower levels of $\mathrm{N}, \mathrm{P}_{2} \mathrm{O}_{5}$ and $\mathrm{K}_{2} \mathrm{O}$. The results of this study provide a new knowledge to produce oil palm plant with better nutrient management at the nursery under solution culture.
\end{abstract}

Key words: growth parameters, solution culture, oil palm, optimum level.

\section{INTRODUCTION}

Oil palm (Elaeis guineensis, Jacq) is an important perennial crop in Malaysia, Indonesia, Columbia, and some African countries. In 2013, the total exports of oil palm products accounted for RM61.36 billion of national gross income; thus making Malaysia one of the largest producers and exporters in the world (MPOB, 2013). Oil palm is the highest yielding oil crop $\left(\mathrm{t} \mathrm{ha}^{-1}\right)$ in the world (Corley \& Tinker, 2003). High yield quality crops can be obtained by supplying optimum mineral nutrition. Mineral nutrition involves the supply, absorption, and utilization of the essential nutrients required for successful growth and yield of the crop plants (Fageria et al., 2010). Levels of $\mathrm{N}, \mathrm{P}_{2} \mathrm{O}_{5}, \mathrm{~K}_{2} \mathrm{O}$ and water are considered as the major limiting factors in crop growth, development and finally economic yield (Glass, 2003; Parry et al., 2005).
Nitrogen is the most important nutrient element in terms of plant growth, physiology and carbohydrate content (Almodares et al., 2008). It is a constituent of chlorophyll, amino acids, proteins, alkaloids, and protoplasm. Phosphorus is the second most limiting nutrient in crop production, playing its most critical role in plants in energy transfer and storage. It is a structural component of nucleic acids, nucleotides, and coenzymes. Low availability is a limiting factor to plant growth (Fita et al., 2011). Potassium is important for maintaining osmotic balance, phloem transport, and photosynthesis (Tripler et al., 2006).

Maintaining a balanced nutrition has an important role in determining plant resistance or susceptibility to disease (Fageria et al., 2010). Moreover, improving nutrient use efficiency (NUE) of crop plants leads to a substantial 
enhancement of the plant yields to satisfy growing food demand, while concurrently reducing the environmental impacts of agriculture (Lobell, 2007). Many studies have been carried out on the balance nutrient uptake under soil based plants (García-Palacios et al., 2014; Bloomfield et al., 2014; Koorem et al., 2014). However, in soil based plant experiment, there exists a complex interaction between the plant, the soil and microbes which may attribute to competitive effects and does not reflect the real $\mathrm{N}, \mathrm{P}_{2} \mathrm{O}_{5}$ and $\mathrm{K}_{2} \mathrm{O}$ nutrients taken up and utilized by the plants precisely. Furthermore, in soil medium there exist a complex interaction between ions within soil particles (Conn et al., 2013). For $\mathrm{P}$ nutrition, hydroponic trial is a better way to determine the $\mathrm{P}_{2} \mathrm{O}_{5}$ optimum level because applied $\mathrm{P}$ fertilizers in soil medium become precipitated by complexes with $\mathrm{Fe}, \mathrm{Al}$, and $\mathrm{Ca}$ in the soils immediately after application, thus does not give the correct amount available for the plant uptake. Hydroponically grown plants (plants cultivated in a soil-free growing system, where a controlled nutrient-rich solution supplies plant roots with nourishment) have been shown to have faster growth rate than soil based plants and are an ideal medium and platform for conveniently evaluating whole plant physiology (Conn et al., 2013). Furthermore, correct nutrient management at nursery stage could avoid wastage and reduces losses of fertilizer. Hydroponic medium give higher yield per unit measured area, continuous year round production, higher quality and ease of processing of harvested product due to minimal contamination from pollutants, pests and pathogens (Pardossi et al., 2006) and most importantly an easy handling of the nutrient profile of the growth medium. In this study, the effect of different levels of $\mathrm{N}, \mathrm{P}_{2} \mathrm{O}_{5}$ and $\mathrm{K}_{2} \mathrm{O}$ for oil palm seedlings in solution culture on growth, physiological, nutrient uptake in plant tissues and biomass accumulation have been carried out under nursery conditions.

\section{MATERIAL AND METHOD}

\section{Study site and plant materials}

The experiment was conducted in the Experimental Farm, No. 2, Universiti Putra Malaysia, Serdang, Selangor, Malaysia ( $\left.2^{\circ} 59^{\prime} 20.56^{\prime \prime} \mathrm{N}, 101^{\circ} 42^{\prime} 44.42^{\prime \prime} \mathrm{E}\right)$ under nursery glasshouse conditions for 182 days between April - October, 2012. The trial was set up in plastic pails $(20 \mathrm{~cm}$ diameter $\times 16 \mathrm{~cm}$ depth). Plant materials consist of pre-germinated seeds, Dura $\times$ Pisifera (F0046 × 1 HP60) purchased from FELDA Plantations Sdn. Bhd, Sungai Tekam, Jerantut, Pahang, Malaysia. Hydroponic media consisting of distilled water and various prepared concentrations of Hoagland solution (A and B) were employed to provide a calculated five nutrient levels for the primary elements of $\mathrm{N}, \mathrm{P}_{2} \mathrm{O}_{5} \mathrm{~K}_{2} \mathrm{O}$ were prepared, respectively. The prepared solution was then applied to the growing seedlings.

\section{Growth conditions, treatments and experimental design}

The germinated oil palm seedlings were raised in polypropylene trays, kept moist with distilled water and wool, and replaced every three days for 2 weeks. Oil palm seedlings of uniform plant height were selected. The nutrient solution used as the plant growth media was prepared according to Hoagland with some modifications (Hoagland \& Arnon, 1950). The $\mathrm{pH}$ of the culture solution was adjusted to 5.5 with $0.1 \mathrm{~N} \mathrm{NaOH}$ or $0.1 \mathrm{~N} \mathrm{HCl}$, and monitored. Electrical conductivity (EC) reading was also monitored to ensure it remains within the recommended range of 0.1-4.0 mmhos. The solution was permanently aerated using an air pump and was renewed every 14 days to guarantee an adequate nutrient supply and replenishment needs for the growing seedlings. Each seedling was fixed onto foam to hold the seedlings erect and placed on perforated white polystyrene covered with black plastic onto individual polypropylene pail containing 2.0 L of nutrient solution. Treatment levels consisted of 50 , $100,300,600$ and $900 \mathrm{mg} \mathrm{L}^{-1}$ concentrations of $\mathrm{N}$ and $\mathrm{K}_{2} \mathrm{O}$ and $15,30,60,90$ and $120 \mathrm{mg} \mathrm{L}^{-1}$ concentrations of $\mathrm{P}_{2} \mathrm{O}_{5}$ laid out in a completely randomized design (CRD) with 5 replications and a total of 75 experimental units

\section{Data collection on growth r parameters}

Several growth parameters were measured during the growing period. Plant height, leaf number/plant, stem diameter and physiological parameters including SPAD chlorophyll content were recorded at a biweekly interval beginning 98 DAT. Measurement of stem diameter was made using a digital caliper. The chlorophyll $(\mathrm{Chl})$ value in the third leaf was determined with a SPAD Chl meter (SPAD-502 Minolta) following the Benton Jones method (Jones, 2003). The Chl value (commonly called SPAD Chl value) of each leaf was the average of five measurements. In the course of the experiment, some deficiency and/or toxicity symptoms were noted and recorded.

\section{Biomass measurement}

The plants were destructively sampled at 182 days (harvest period). Plants were partitioned into shoots and roots and the dry weights - root dry weight, shoot dry weight, total dry weight, total leaf area and root shoot ratio, were recorded and nutrient partitioned. Nutrient analysis for N, P and $\mathrm{K}$ nutrient uptake in the tissue was performed. 


\section{Sample preparation and analysis}

After drying, all the plant components were separately ground and sub-sampled. Oven-dried shoot and roots $(250 \mathrm{mg})$ were digested in $5 \mathrm{~mL}$ sulfuric acid in a block digester at $330{ }^{\circ} \mathrm{C}$ for 2 hours. Hydrogen peroxide (4-5 drops) was added after which the samples were placed in a digester for 1 hour (Gupta, 2007). Digested solutions were filtered through Whatman filter paper No. 44 and made up to $50 \mathrm{~mL}$ with distilled water in volumetric flasks. The concentrations of $\mathrm{N}$ and $\mathrm{P}$ in solution were determined using an auto-analyzer (QuikChem, Series 8000, Lachat Instruments Inc., USA) and the concentration of $\mathrm{K}$ was measured using atomic absorption spectrophotometer (Perkin-Elmer 5100 PC).

\section{Statistical analysis}

Data were averaged over the replications for all measuring dates and their means were used in deriving relationships between growth and nutrient uptake parameters. The differences in growth and nutrition between the $\mathrm{N}, \mathrm{P}_{2} \mathrm{O}_{5}$ and $\mathrm{K}_{2} \mathrm{O}$ treatments were calculated using the SAS statistical procedure, PROC ANOVA, Duncan's Multiple Range Test (DMRT; $\mathrm{p}<0.05$ ) was used to detect significant grouping among the treatments.

\section{RESULTS AND DISCUSSION}

\section{Effect of nitrogen levels on oil palm seedlings growth}

The results of growth parameters outlined in Table 1, indicated all plant traits measured - total leaf area and root shoot ratio indicated highly significant $(\mathrm{p}<0.001)$ difference among the treatment levels, while plant height, stem diameter, number of leaf/plant indicated significant difference $(\mathrm{p}<0.05)$. Level $\mathrm{N} 2\left(100 \mathrm{mg} \mathrm{L}^{-1}\right)$ recording the highest value which began to decline significantly as the $\mathrm{N}$ levels were raised. The physiological parameter indicated only SPAD Chl values was significantly different $(\mathrm{p}<0.05)$ among the $\mathrm{N}$ treatment levels.

The total leaf area at level N2 was significantly higher $\left(383.16 \mathrm{~cm}^{2}\right)$ and began to decline significantly as the $\mathrm{N}$ level was raised to $300 \mathrm{mg} \mathrm{L}^{-1}$. The lowest treatment at $\mathrm{N} 1\left(50 \mathrm{mg} \mathrm{L}^{-1}\right)$ resulted in a $32.8 \%$ reduction in total leaf area. This increased leaf area in N2 despite only slight differences in the leaf number/plant suggest that higher leaf expansion of treated oil palm seedlings were attained. This study suggested that $\mathrm{N}$ nutrition at deficiency affected more strongly the leaf development rather than the photosynthesis. Moreover, $\mathrm{N}$ deficiency has great impact on chloroplast in size, composition and function (Lawlor \& Cornic, 2002). On the other hand, the higher rates, N4 and N5 attain the level of toxicity and retard the plant growth and this could also be attributed to toxicity of the nutrient at higher levels, where the symptoms of necrosis of the oil palm seedlings' leaves initially were observed and eventually the whole plants died.

In solution culture experiment, $\mathrm{N}$ is absorbed in large quantity and the forms, such as $\mathrm{NO}_{3}^{-}$(anion) or $\mathrm{NH}_{4}^{+}$(cation), in which this element is supplied exerts a great influence on $\mathrm{pH}$ change and $\mathrm{pH}$ in turn affect in unequal absorption of cations and anions and nutrient availability in solution culture.

\section{Effect of phosphorus levels on oil palm seedlings growth}

Multiple mean comparisons of the growth parameters in table 2 indicated plant traits measured - leaf area, root shoot ratio, SPAD Chl value, - were highly significant $(\mathrm{p}<0.001)$ difference among the treatment levels, while plant height and stem diameter gave the highest values among the treatment levels. Overall, P4 $\left(90 \mathrm{mg} \mathrm{L}^{-1}\right)$ were optimum for plant height, stem diameter, total leaf area, and root shoot ratio. The higher level of $\mathrm{P}_{2} \mathrm{O}_{5}$ nutrition caused the highest increase $(34.50 \mathrm{~cm})$ in plant height at P4. Similarly, the SPAD Chl value was significantly influenced by the level of $\mathrm{P}_{2} \mathrm{O}_{5}$. In treatment $\mathrm{P} 1\left(15 \mathrm{mg} \mathrm{L}^{-1}\right)$, total leaf area was reduced $\left(193.79 \mathrm{~cm}^{2}\right)$, a $70.4 \%$ reduction from the optimum values and leaves were observed to be shorter as affected by

Table 1. Mean comparison of nitrogen nutrition for growth and parameter at harvest, 182 DAT

\begin{tabular}{|c|c|c|c|c|c|}
\hline Treatment level & N1 & N2 & N3 & N4 & N5 \\
\hline Concentration (mg L-1) & 50 & 100 & 300 & 600 & 900 \\
\hline Plant height (cm) & $29.10 \pm 0.96^{b c}$ & $33.22 \pm 1.02^{a}$ & $31.62 \pm 1.18^{\mathrm{ab}}$ & $28.74 \pm 1.55^{b c}$ & $22.66 \pm 2.14^{c}$ \\
\hline Stem diameter (mm) & $12.18 \pm 0.57^{a}$ & $11.84 \pm 0.72^{a}$ & $10.36 \pm 0.22^{a b}$ & $8.35 \pm 0.50^{b}$ & $8.30 \pm 0.20^{b}$ \\
\hline Leaf no. plant $^{-1}$ & $4.30 \pm 0.15^{\mathrm{ab}}$ & $4.60 \pm 0.24^{a}$ & $4.60 \pm 0.18^{a}$ & $4.00 \pm 0.0^{b}$ & $3.90 \pm 0.24^{b}$ \\
\hline Leaf area $\left(\mathrm{cm}^{2}\right)$ & $257.42 \pm 13.46^{\mathrm{b}}$ & $383.16 \pm 7.69^{a}$ & $211.98 \pm 16.42^{c}$ & $103.12 \pm 4.43^{d}$ & $70.70 \pm 3.02^{\circ}$ \\
\hline Root shoot ratio & $0.14 \pm 0.03^{b}$ & $0.19 \pm 0.04^{a}$ & $0.12 \pm 0.02^{b}$ & $0.10 \pm 0.01^{b}$ & $0.10 \pm 0.03^{b}$ \\
\hline SPAD chl value & $54.40 \pm 1.75^{\mathrm{a}}$ & $57.74 \pm 1.25^{\mathrm{a}}$ & $52.40 \pm 2.07^{a}$ & $36.50 \pm 1.53^{b}$ & $22.03 \pm 2.01^{b}$ \\
\hline
\end{tabular}

Means sharing similar letter in a column are statistically non-significant $(\mathrm{p}>0.05) ; \pm$ values indicates the standard error $(\mathrm{n}=5)$. 
$\mathrm{P}_{2} \mathrm{O}_{5}$ deficiency. Increasing the levels of $\mathrm{P}_{2} \mathrm{O}_{5}$ treatments, significantly increase $(\mathrm{p}<0.001)$ the root shoot ratio by a $45.5 \%$. Phosphorus nutrition have caused greater percentage of assimilate partitioned towards the roots, thus this lead to an increase in the root shoot ratio. The P1 treatment was too low to impact on the growth parameters, while the higher rate was too toxic to allow proper growth. As observed in this present study, P deficiency had reduced leaf expansion, leaf surface area, and the number of leaves and this was later on reflected in lower biomass production at harvest. This is due to inadequate $\mathrm{P}$ slows the processes of carbohydrate metabolism including photosynthesis and respiration, which results in a buildup of carbohydrates and the development of a dark green leaf color. In addition, leaf edges turn scorched brown in deficiency of $\mathrm{P}$.

\section{Effect of potassium levels on oil palm seedlings growth}

Overall, multiple mean comparisons of all the $\mathrm{K}_{2} \mathrm{O}$ treatments (Table 3) indicated all plant growth traits measured - plant height, stem diameter, leaf area, $(\mathrm{p}<0.001)$ number of leaf plant $(\mathrm{p}<0.05)$ indicated significant difference among the treatment levels, with $\mathrm{K} 3\left(300 \mathrm{mg} \mathrm{L}^{-1}\right)$ recording the highest reading and declining significantly as the $\mathrm{K}_{2} \mathrm{O}$ levels were raised. At K1, the lowest treatment levels for $\mathrm{K}_{2} \mathrm{O}\left(50 \mathrm{mg} \mathrm{L}^{-1}\right)$ resulted in $43.8 \%$ increase in total leaf area. It can be noticed that optimum concentration of $\mathrm{K}$ element in nutrient solution led to maximum plant height, stem diameter, leaf area and other growth traits.

\section{Effect of $\mathrm{N}, \mathrm{P}_{2} \mathrm{O}_{5}$ and $\mathrm{K}_{2} \mathrm{O}$ nutrition on dry weight, total biomass and proportion of biomass partitioning}

Among all the growth parameters, dry biomass accumulation confirms the positive effects of a balanced nutrition and the importance of these $\mathrm{N}, \mathrm{P}_{2} \mathrm{O}_{5}$ and $\mathrm{K}_{2} \mathrm{O}$ nutrition on the oil palm growth performance. For $\mathrm{N}$ treatment in Table 4, all of dry biomass i.e. shoot dry weight, root dry weight and total plant biomass for $\mathrm{N}$ treatment indicated highly significant (0.001) difference among the treatment levels. Highest shoot dry weight values, 2.35 and $1.85 \mathrm{~g} \mathrm{plant}^{-1}$, were obtained with the first two lower levels of $\mathrm{N}$ concentrations (100 and $50 \mathrm{mg} \mathrm{L}^{-1}$ respectively), being significantly different $(\mathrm{p} \leq 0.001)$. Treatment level of $\mathrm{N} 2\left(100 \mathrm{mg} \mathrm{L}^{-1}\right)$ gave the optimum value for most of the agronomic parameters studied and is recommended to attain optimum seedling growth

in oil palm. The higher $\mathrm{N}$ rate did not have positive impact on the growth parameters studied. A gradual significant decrease in the shoot dry matter was noted as $\mathrm{N}$ concentration was raised to $300 \mathrm{mg} \mathrm{L}^{-1}$ and further raised to 600 and $900 \mathrm{mg} \mathrm{L}^{-1}$ levels with the values declining to $1.56,1.10$, and $0.63 \mathrm{~g} \mathrm{plant}^{-1}$, respectively. The higher rates attain the level of toxicity and retard the plant growth rate and dry matter accumulation.

For biomass accumulation with $\mathrm{P}_{2} \mathrm{O}_{5}$ treatment, treatment level P4 (90 $\left.\mathrm{mg} \mathrm{L}^{-1}\right)$ was considered the optimum for the growth parameters studied. The P concentration applied gave the highest shoot dry weight $\left(2.79 \mathrm{~g} \mathrm{plant}^{-1}\right)$ that was significantly different from the other four applied levels. The least shoot dry weight yield (1.35 and $\left.1.42 \mathrm{~g} \mathrm{plant}^{-1}\right)$ were obtained from the lowest applied P concentration

Table 2. Mean comparison of phosphorus nutrition for growth and parameter at harvest, 182 DAT

\begin{tabular}{|c|c|c|c|c|c|}
\hline Treatment level & P1 & P2 & P3 & P4 & P5 \\
\hline Concentration (mg L ${ }^{-1}$ ) & 15 & 30 & 60 & 90 & 120 \\
\hline Plant height (cm) & $29.56 \pm 0.55^{a}$ & $32.04 \pm 1.40^{\mathrm{a}}$ & $29.16 \pm 2.21^{a}$ & $34.50 \pm 1.95^{a}$ & $31.16 \pm 2.13^{a}$ \\
\hline Leaf no. plant $^{-1}$ & $4.60 \pm 0.19^{a b}$ & $5.00 \pm 0.10^{a}$ & $4.20 \pm 0.20^{b}$ & $4.80 \pm 0.20^{a}$ & $4.20 \pm 0.20^{b}$ \\
\hline Leaf area $\left(\mathrm{cm}^{2}\right)$ & $193.79 \pm 2.48^{e}$ & $353.99 \pm 3.93^{c}$ & $427.91 \pm 1.68^{b}$ & $654.33 \pm 6.02^{\mathrm{a}}$ & $238.73 \pm 2.51^{d}$ \\
\hline Root shoot ratio & $0.072 \pm 0.004^{e}$ & $0.116 \pm 0.004^{d}$ & $0.148 \pm 0.008^{b}$ & $0.182 \pm 0.003^{a}$ & $0.132 \pm 0.004^{c}$ \\
\hline SPAD chl value & $50.17 \pm 1.32^{b}$ & $52.76 \pm 1.70^{a}$ & $54.62 \pm 2.13^{a}$ & $55.20 \pm 1.04^{a}$ & $50.36 \pm 2.01^{b}$ \\
\hline
\end{tabular}

Means sharing similar letter in a column are statistically non-significant $(\mathrm{p}>0.05)$; \pm values indicates the standard error $(n=5)$.

Table 3. Mean comparison of potassium nutrition for growth and parameter at harvest, 182 DAT

\begin{tabular}{|c|c|c|c|c|c|}
\hline Treatment level & K1 & K2 & K3 & K4 & K5 \\
\hline Concentration (mg L-1) & 50 & 100 & 300 & 600 & 900 \\
\hline Plant height (cm) & $32.82 \pm 0.94^{\mathrm{ab}}$ & $36.53 \pm 1.42^{a}$ & $36.62 \pm 1.16^{a}$ & $30.26 \pm 1.06^{b}$ & $28.52 \pm 1.18^{b}$ \\
\hline Stem diameter (mm) & $13.18 \pm 0.80^{a}$ & $13.72 \pm 0.43^{a}$ & $13.76 \pm 0.61^{a}$ & $11.32 \pm 0.23^{a b}$ & $10.46 \pm 0.30^{b}$ \\
\hline Leaf no. plant $^{-1}$ & $4.60 \pm 0.39^{a}$ & $4.70 \pm 0.12^{a}$ & $4.70 \pm 0.12^{a}$ & $3.90 \pm 0.10^{a b}$ & $4.10 \pm 0.10^{a b}$ \\
\hline Leaf area $\left(\mathrm{cm}^{2}\right)$ & $289.36 \pm 30.23^{b}$ & $477.56 \pm 40.91^{a}$ & $515.02 \pm 32.43^{a}$ & $302.08 \pm 26.28^{b}$ & $224.92 \pm 27.07^{b}$ \\
\hline Root shoot ratio & $0.12 \pm 0.02^{a}$ & $0.16 \pm 0.02^{a}$ & $0.16 \pm 0.02^{a}$ & $0.12 \pm 0.02^{\mathrm{a}}$ & $0.12 \pm 0.02^{a}$ \\
\hline SPAD chl value & $49.42 \pm 1.30^{b}$ & $51.66 \pm 1.93^{b}$ & $56.92 \pm 1.21^{\mathrm{a}}$ & $49.72 \pm 0.83^{b}$ & $49.52 \pm 2.09^{b}$ \\
\hline
\end{tabular}

Means sharing similar letter in a column are statistically non-significant $(p>0.05)$; \pm values indicates the standard error $(n=5)$. 
Table 4. Effect of $\mathrm{N}, \mathrm{P}_{2} \mathrm{O}_{5}$ and $\mathrm{K}_{2} \mathrm{O}$ nutrition on oil palm dry weight, proportion of biomass accumulation and total biomass accumulation at harvest, 182 DAT

\begin{tabular}{|c|c|c|c|c|}
\hline \multirow{2}{*}{ Treatment } & \multirow{2}{*}{ Level } & \multicolumn{3}{|c|}{$\mathrm{N}$ nutrition (g plant ${ }^{-1},(\%)$ ) } \\
\hline & & Shoot Dry Wt & Root Dry Wt & Total \\
\hline N1 & 50 & $1.85 \pm 0.21^{\mathrm{b}}(86.4)$ & $0.29 \pm 0.03^{b}(13.6)$ & $2.14 \pm 0.14^{b}$ \\
\hline N2 & 100 & $2.35 \pm 0.16^{a}(84.5)$ & $0.43 \pm 0.04^{a}(16.3)$ & $2.78 \pm 0.19^{a}$ \\
\hline N3 & 300 & $1.56 \pm 0.09^{c}(89.7)$ & $0.18 \pm 0.02^{c}(10.3)$ & $1.74 \pm 0.09^{\mathrm{bc}}$ \\
\hline N4 & 600 & $1.10 \pm 0.14^{\mathrm{cd}}(90.9)$ & $0.11 \pm 0.01^{\mathrm{c}}(9.1)$ & $1.21 \pm 0.15^{\mathrm{cd}}$ \\
\hline \multirow[t]{3}{*}{ N5 } & 900 & $0.63 \pm 0.02^{d}(90.0)$ & $0.07 \pm 0.02^{\mathrm{d}}(10.0)$ & $0.70 \pm 0.02^{d}$ \\
\hline & & \multicolumn{3}{|c|}{ P nutrition (g plant ${ }^{-1},(\%)$ ) } \\
\hline & & Shoot Dry Wt & Root Dry Wt & Total \\
\hline P1 & 15 & $1.35 \pm 0.09^{c}(86.0)$ & $0.22 \pm 0.04^{\mathrm{a}}(9.4)$ & $1.57 \pm 0.12^{c}$ \\
\hline P2 & 30 & $2.36 \pm 0.15^{\mathrm{b}}(86.8)$ & $0.36 \pm 0.03^{a}(13.2)$ & $2.72 \pm 0.16^{\mathrm{ab}}$ \\
\hline P3 & 60 & $2.13 \pm 0.05^{b}(86.6)$ & $0.33 \pm 0.03^{a}(13.4)$ & $2.46 \pm 0.07^{b}$ \\
\hline P4 & 90 & $2.79 \pm 0.17^{a}(88.3)$ & $0.37 \pm 0.03^{a}(11.7)$ & $3.16 \pm 0.17^{\mathrm{a}}$ \\
\hline \multirow[t]{3}{*}{ P5 } & 120 & $1.42 \pm 0.12^{\mathrm{c}}(81.1)$ & $0.33 \pm 0.14^{a}(18.9)$ & $1.75 \pm 0.18^{c}$ \\
\hline & & \multicolumn{3}{|c|}{$\mathrm{K}$ nutrition (g plant $\left.{ }^{-1},(\%)\right)$} \\
\hline & & Shoot Dry Wt & Root Dry Wt & Total \\
\hline K1 & 50 & $2.20 \pm 0.30^{\mathrm{b}}(87.3)$ & $0.32 \pm 0.03^{c}(12.7)$ & $2.52 \pm 0.32^{b}$ \\
\hline K2 & 100 & $3.26 \pm 0.25^{a}(86.5)$ & $0.51 \pm 0.02^{b}(13.5)$ & $3.77 \pm 0.25^{a}$ \\
\hline K3 & 300 & $3.50 \pm 0.15^{a}(85.0)$ & $0.62 \pm 0.03^{a}(15.0)$ & $4.12 \pm 0.15^{a}$ \\
\hline K4 & 600 & $1.98 \pm 0.17^{b}(88.4)$ & $0.26 \pm 0.02^{c}(11.6)$ & $2.24 \pm 0.19^{b}$ \\
\hline K5 & 900 & $1.62 \pm 0.11^{\mathrm{b}}(87.1)$ & $0.24 \pm 0.05^{c}(12.9)$ & $1.86 \pm 0.15^{b}$ \\
\hline
\end{tabular}

Means sharing similar letter in a column for different levels of the same nutrient are statistically non-significant according to Duncan's Multiple Range Test (DMRT) at $\alpha=0.05$; values are the means of five replicates \pm standard error.

in P1 $\left(15 \mathrm{mg} \mathrm{L}^{-1}\right)$ and the highest in P5 (120 $\left.\mathrm{mg} \mathrm{L}^{-1}\right)$, respectively, and both were not significantly different. At P1 level was too low to impact on the growth parameters, while P5 was too toxic to allow for proper growth. Root dry weight was not significantly affected by the treatment levels but $\mathrm{P} 4$ gave the highest root dry weight.

Phosphorus concentrations in $\mathrm{P} 4$ and $\mathrm{P} 2$ gave the highest total dry matter of 3.16 and $2.72 \mathrm{~g} \mathrm{plant}^{-1}$, respectively, with no significant difference between the two levels. Similarly lowest total dry matter of 1.75 and $1.57 \mathrm{~g} \mathrm{plant}^{-1}$ was obtained from the highest (P5) and lowest (P1) applied $\mathrm{P}$ concentrations, respectively, with no significant difference between the two.

Applied Klevels in K2 and K3 (100 and $300 \mathrm{mg} \mathrm{L}^{-1}$ respectively) gave the highest shoot dry weight values of 3.26 and $3.50 \mathrm{~g}$ plant ${ }^{-1}$ respectively, with the difference between the two being insignificant. Lower shoot dry weight values of 2.20, 1.98, and $1.62 \mathrm{~g} \mathrm{plant}^{-1}$ came from the remaining 3 treatment levels of 50,600, and $900 \mathrm{mg} \mathrm{L}^{-1}$, respectively, with the difference between them being insignificant. Potassium applied concentration of $300 \mathrm{mg} \mathrm{L}^{-1}$ gave a correspondingly significantly high root dry weight value $\left(0.62 \mathrm{~g} \mathrm{plant}^{-1}\right)$ than the other applied treatment levels. Lowest root dry weight value came from 3 applied $\mathrm{K}$ concentrations of 50, 600, and $900 \mathrm{mg} \mathrm{L}^{-1}$, with no significant difference between them.

Highest total dry weight values of 3.77 and $4.12 \mathrm{~g} \mathrm{plant}^{-1}$ were obtained from applied K levels of 100 and $300 \mathrm{mg} \mathrm{L}^{-1}$, respectively. Overall, total plant biomass accumulated in the plant was affected significantly by the different levels of $\mathrm{N}$, $\mathrm{P}_{2} \mathrm{O}_{5}$ and $\mathrm{K}_{2} \mathrm{O}$ treatment, with the optimum values of 2.78, 3.16 and $4.12 \mathrm{~g} /$ plant at N2, P4 and K3 levels obtained.

For proportion of biomass partitioning in table 4, all the three treatments indicated shoots portion consisting of leaf, stem and stem accounted for the greatest proportion of dry matter partitioning, 81.1-90.9\%, while root accounted only $9.1-18.9 \%$, respectively.

\section{Effect of $\mathbf{N}, \mathbf{P}_{2} \mathrm{O}_{5}$ and $\mathrm{K}_{2} \mathrm{O}$ nutrition on the nutrient uptake, nutrient concentration and nutrient partitioning in plant parts}

For nutrient uptake (Table 5), all the applied treatment levels indicated higher nutrient uptake in the shoot as compared to the root portion. The highest total $\mathrm{N}$ uptake of $58.03 \mathrm{~g} \mathrm{plant}^{-1}$ was obtained with $100 \mathrm{mg} \mathrm{L}^{-1}$ levels of applied $\mathrm{N}$ with mean comparison portrays the differences as highly significant. Irrespective of the $\mathrm{N}, \mathrm{P}_{2} \mathrm{O}_{5}$ and $\mathrm{K}_{2} \mathrm{O}$ source in the solution culture, highest nutrient uptake for total N, P and K in plant tissue were 71.43, 23.40 and $214.33 \mathrm{mg} \mathrm{plant}^{-1}$ respectively, obtained with treatment applications of 100,90 and $300 \mathrm{mg} \mathrm{L}^{-1}$ with significant different among treatments. Results indicate a distinct role of $\mathrm{N}$ in the export of photosynthesis from leaves to root. The alteration in photosynthetic partitioning plays a major 
role in the differences in dry matter distribution between leaves and roots of plants (Cakmak et al., 1994).

Plant uptake is the most significant removal process in $\mathrm{N}, \mathrm{P}_{2} \mathrm{O}_{5}$ and $\mathrm{K}_{2} \mathrm{O}$ cycling. For any actively growing plants, anything that affects the metabolism of the plant will affect nutrient uptake. Elevating the total $\mathrm{N}_{2} \mathrm{P}_{2} \mathrm{O}_{5}$ and $\mathrm{K}_{2} \mathrm{O}$ levels (Table 6) had significantly decreased total $\mathrm{N}, \mathrm{P}_{2} \mathrm{O}_{5}$ and $\mathrm{K}_{2} \mathrm{O}$ in total nutrient uptake. Potassium levels were found to have similar trend with $\mathrm{N}$ (Table 6) in the assessed tissue parts, with concentration up to the highest rate tested in this study. By comparing the same rate of $\mathrm{N}$ and $\mathrm{K}_{2} \mathrm{O}$ treatment, K uptake greatly exceeds $\mathrm{N}$ uptake (more than 3 folds) in the total nutrients uptake in oil palm tissue. However, highest levels of nutrient concentration and nutrient uptake did not give the highest plant biomass accumulation though. These could be attributed to nutrient imbalances at higher levels

Table 5. Effect of $\mathrm{N}, \mathrm{P}_{2} \mathrm{O}_{5}$ and $\mathrm{K}_{2} \mathrm{O}$ nutrition on the nutrient uptake in different plant parts at harvest, 182 DAT

\begin{tabular}{|c|c|c|c|c|}
\hline \multirow{2}{*}{ Level } & \multirow{2}{*}{ Treatment $\left(\mathrm{mg} \mathrm{L}^{-1}\right)$} & \multicolumn{3}{|c|}{ N uptake (mg plant ${ }^{-1}$ ) } \\
\hline & & Shoot & Root & Total \\
\hline N1 & 50 & $37.59^{\mathrm{ab}}$ & $8.29^{b}$ & $45.88^{\mathrm{ab}}$ \\
\hline N2 & 100 & $58.03^{a}$ & $13.39^{\mathrm{a}}$ & $71.43^{a}$ \\
\hline N3 & 300 & $51.78^{\mathrm{ab}}$ & $9.18^{\mathrm{ab}}$ & $60.96^{\mathrm{ab}}$ \\
\hline N4 & 600 & $39.07^{\mathrm{ab}}$ & $5.28^{\mathrm{bc}}$ & $44.35^{b c}$ \\
\hline \multirow[t]{3}{*}{ N5 } & 900 & $31.05^{b}$ & $3.08^{c}$ & $34.13^{c}$ \\
\hline & & \multicolumn{3}{|c|}{ P uptake (mg plant ${ }^{-1}$ ) } \\
\hline & & Shoot & Root & Total \\
\hline P1 & 15 & $5.62^{\mathrm{b}}$ & $5.36^{\mathrm{a}}$ & $10.98^{b}$ \\
\hline $\mathrm{P} 2$ & 30 & $8.64^{b}$ & $2.33^{\mathrm{a}}$ & $10.97^{b}$ \\
\hline P3 & 60 & $9.78^{\mathrm{b}}$ & $2.00^{\mathrm{a}}$ & $11.78^{b}$ \\
\hline P4 & 90 & $20.38^{\mathrm{a}}$ & $3.04^{\mathrm{a}}$ & $23.40^{\mathrm{a}}$ \\
\hline \multirow[t]{3}{*}{ P5 } & 120 & $12.21^{\mathrm{b}}$ & $1.52^{\mathrm{a}}$ & $13.72^{\mathrm{a}}$ \\
\hline & & \multicolumn{3}{|c|}{ K uptake (mg plant ${ }^{-1}$ ) } \\
\hline & & Shoot & Root & Total \\
\hline $\mathrm{K} 1$ & 50 & $84.69^{b}$ & $8.55^{c}$ & $93.24^{c}$ \\
\hline $\mathrm{K} 2$ & 100 & $118.11^{\mathrm{b}}$ & $22.77^{\mathrm{ab}}$ & $140.88^{\mathrm{ab}}$ \\
\hline K3 & 300 & $181.04^{\mathrm{a}}$ & $33.29^{a}$ & $214.33^{a}$ \\
\hline K4 & 600 & $125.16^{\mathrm{ab}}$ & $16.32^{\mathrm{bc}}$ & $141.48^{\mathrm{bc}}$ \\
\hline K5 & 900 & $180.62^{a}$ & $30.11^{\mathrm{abc}}$ & $320.41^{a b}$ \\
\hline
\end{tabular}

Means sharing similar letter in a column for different levels of the same nutrient are statistically non-significant according to Duncan's Multiple Range Test (DMRT) at $\alpha=0.05$; values are the means of five replicates \pm standard error.

Table 6. Effect of $\mathrm{N}_{2} \mathrm{P}_{2} \mathrm{O}_{5}$, and $\mathrm{K}_{2} \mathrm{O}$ treatment on nutrient concentration and nutrient partitioning of different plant parts at harvest, $182 \mathrm{DAT}$

\begin{tabular}{|c|c|c|c|c|c|c|c|c|c|c|c|c|c|}
\hline \multirow{3}{*}{$\begin{array}{c}\text { Treatment } \\
\text { Level }\end{array}$} & \multicolumn{4}{|c|}{ N (\%) } & \multicolumn{4}{|c|}{$\mathbf{P}(\%)$} & \multicolumn{4}{|c|}{ K (\%) } & \multirow{3}{*}{$\begin{array}{c}\text { Total } \\
(\%)\end{array}$} \\
\hline & \multicolumn{2}{|l|}{ Shoot } & \multicolumn{2}{|l|}{ Root } & \multicolumn{2}{|l|}{ Shoot } & \multicolumn{2}{|l|}{ Root } & \multicolumn{2}{|l|}{ Shoot } & \multicolumn{2}{|l|}{ Root } & \\
\hline & Conc* & Part* & Conc & Part & Conc & Part & Conc & Part & Conc & Part & Conc & Part & \\
\hline N1 & $2.11 \pm 0.23^{c}$ & 32.4 & $3.18 \pm 0.21^{c}$ & 7.0 & $3.69 \pm 0.49^{b}$ & 5.7 & $0.62 \pm 0.01^{a}$ & 1.4 & $2.74 \pm 0.04^{\mathrm{ab}}$ & 42.1 & $5.19 \pm 0.13^{\mathrm{ab}}$ & 11.4 & 100 \\
\hline N2 & $2.88 \pm 0.03^{b}$ & 38.3 & $3.62 \pm 0.19^{c}$ & 8.9 & & 4.7 & & 1.6 & & 32.7 & $5.57 \pm 0.36^{a}$ & 13.7 & 100 \\
\hline N3 & $3.37 \pm 0.13^{b}$ & 44.3 & $4.96 \pm 0.37^{b}$ & 7.9 & $4.96 \pm 0.37^{a}$ & 6.5 & $0.64 \pm 0.01^{a}$ & 1.2 & $2.41 \pm 0.14^{\text {bc }}$ & 31.7 & $4.60 \pm 0.14^{b}$ & 8.3 & 100 \\
\hline N4 & $3.53 \pm 0.10^{b}$ & 27.0 & $4.93 \pm 0.09^{a}$ & 6.0 & $4.38 \pm 0.45^{\mathrm{ab}}$ & 5.5 & $0.64 \pm 0.01^{a}$ & 0.8 & $2.88 \pm 0.18^{a}$ & 36.5 & $5.28 \pm 0.04^{\mathrm{ab}}$ & 6.5 & 100 \\
\hline N5 & $4.93 \pm 0.43^{a}$ & 39.0 & $4.64 \pm 0.05^{\mathrm{ab}}$ & 5.9 & $4.10 \pm 0.17^{\mathrm{ab}}$ & 4.9 & $0.54 \pm 0$. & 0.7 & & 25.6 & & 3.9 & 100 \\
\hline $\mathrm{P} 1$ & $2.75 \pm 0.28 b^{c}$ & 35.8 & $4.27 \pm 0.08^{a}$ & 10.3 & $0.38 \pm 0.04^{b}$ & 4.9 & $1.84 \pm 1.33^{a}$ & 4.4 & $2.67 \pm 0.28^{a}$ & 34.7 & $4.07 \pm 0.17^{b}$ & 9.8 & 100 \\
\hline P2 & $2.50 \pm 0.08^{c}$ & 39.2 & $4.36 \pm 0.27^{a}$ & 12.2 & $0.38 \pm 0.01^{\mathrm{b}}$ & 6.0 & $0.58 \pm 0.03^{a}$ & 1.6 & $1.88 \pm 0.05^{b}$ & 29.5 & $4.13 \pm 0.10^{b}$ & 11.5 & 100 \\
\hline P3 & $2.39 \pm 0.08^{c}$ & 38.5 & $4.28 \pm 0.13^{a}$ & 9.8 & $0.42 \pm 0.02^{b}$ & 6.8 & $0.60 \pm 0.02^{a}$ & 1.4 & $2.00 \pm 0.09^{b}$ & 32.2 & $4.98 \pm 0.29^{a}$ & 11.4 & 100 \\
\hline P4 & $3.50 \pm 0.10^{a}$ & 42.4 & $4.39 \pm 0.03^{a}$ & 9.3 & $1.00 \pm 0.13^{a}$ & 12.2 & $0.87 \pm 0.00^{a}$ & 1.8 & $1.99 \pm 0.11^{b}$ & 24.1 & $4.79 \pm 0.17^{a}$ & 10.1 & 100 \\
\hline P5 & $3.11 \pm 0.15^{\mathrm{ab}}$ & 44.4 & $4.51 \pm 0.24^{\mathrm{a}}$ & 4.8 & $0.51 \pm 0.02^{b}$ & 7.3 & $0.85 \pm 0.06^{a}$ & 0.9 & $2.60 \pm 0.17^{a}$ & 37.2 & $4.99 \pm 0.06^{a}$ & 5.3 & 100 \\
\hline K1 & $4.76 \pm 0.08^{b}$ & 48.4 & $4.47 \pm 0.08^{\mathrm{ab}}$ & 5.1 & $0.90 \pm 0.07^{\mathrm{ab}}$ & 9.1 & $0.60 \pm 0.06^{a}$ & 0.7 & $3.27 \pm 0.07^{d}$ & 33.3 & $3.04 \pm 0.32^{c}$ & 3.4 & 100 \\
\hline $\mathrm{K} 2$ & $6.11 \pm 0.12^{\mathrm{a}}$ & 47.7 & $5.09 \pm 0.09^{a}$ & 6.3 & $1.15 \pm 0.12^{\mathrm{ab}}$ & 9.0 & $0.90 \pm 0.01^{a}$ & 1.1 & $3.84 \pm 0.07^{d}$ & 30.0 & $4.64 \pm 0.19^{b c}$ & 5.8 & 100 \\
\hline K3 & $6.01 \pm 0.23^{a}$ & 42.9 & $4.47 \pm 0.08^{\mathrm{ab}}$ & 5.4 & $1.19 \pm 0.13^{a}$ & 8.5 & $0.78 \pm 0.13^{a}$ & 0.9 & $5.00 \pm 0.40^{c}$ & 35.7 & $5.49 \pm 0.10^{b}$ & 6.6 & 100 \\
\hline K4 & $5.53 \pm 0.41^{\mathrm{ab}}$ & 39.9 & $3.84 \pm 0.17^{b c}$ & 3.3 & $0.88 \pm 0.08^{\mathrm{ab}}$ & 6.3 & $0.70 \pm 0.04^{a}$ & 0.6 & $6.11 \pm 0.17^{b}$ & 44.0 & $6.80 \pm 0.38^{\mathrm{ab}}$ & 5.9 & 100 \\
\hline K5 & $5.63 \pm 0.35^{a b}$ & 31.0 & $3.64 \pm 0.36^{c}$ & 2.8 & $0.86 \pm 0.00^{b}$ & 4.7 & $0.71 \pm 0.05^{a}$ & 0.6 & $9.95 \pm 0.39^{a}$ & 54.7 & $7.91 \pm 1.51^{\mathrm{a}}$ & 6.2 & 100 \\
\hline
\end{tabular}

Means sharing similar letter in a column for different levels of the same nutrient are statistically non-significant according to Duncan's Multiple Range Test (DMRT) at $\alpha=0.05$; values are the means of five replicates \pm standard error. ${ }^{*}$ Conc $=$ Concentration, Part $=$ Partitioning. 
affecting the physiological, biochemical processes and retard growth of the oil palm seedlings. For instant, nutrient uptake in plant tissues for $\mathrm{K} 4$ and $\mathrm{K} 5$, indicated no corresponding increase in growth parameters and is reflected in the reduced total dry biomass at K4 and K5. Similarly, for N treatment, despite significantly higher shoot and root $\mathrm{N}$ content in $\mathrm{N} 4$ and $\mathrm{N} 5$, respectively, no corresponding increase of total biomass accumulated (Table 4). These cases shed some light on the antagonistic interaction among the nutrients, thus resulted in inefficient and uneconomical utilization of $\mathrm{N}$ and $\mathrm{K}$ nutrients in the plant tissues. What is clear is that the rate of nutrient uptake is controlled by the growth rate of plants and related to the physiological requirements.

\section{Effect of $\mathrm{N}, \mathrm{P}_{2} \mathrm{O}_{5}$ and $\mathrm{K}_{2} \mathrm{O}$ nutrition on nutrient concentration and nutrient partitioning in plant parts}

Laboratory analysis conducted to determine nutrient partitioned in oil palm tissues (Table 6) showed that all treatments resulted in higher nutrient concentration were partitioned in shoot parts compared to the root. Within the $\mathrm{N}$ treatment application, indicated significant increase in shoot $\mathrm{N}$ tissue concentration up to the highest rate tested in this study. The N2, N3 and N4 levels were not significantly different with each other, but were significantly different with $\mathrm{N} 1$ and N5, with the highest value of $4.93 \%$ obtained in N5.

In $\mathrm{P}_{2} \mathrm{O}_{5}$ treatment (Table 6), shoot parts for both $\mathrm{N}$ and $\mathrm{P}$ nutrient concentration indicated the highest values at $\mathrm{P} 4$, with the values of 3.50 and $1.00 \%(\mathrm{p}<0.05)$, respectively, both significantly different from all the other $\mathrm{P}$ levels. However, root $\mathrm{P}$ were not significantly different for all P levels in these two treatments. Shoot part indicated the highest $\mathrm{K}$ nutrient concentration value at P5 and were significantly different compared with other levels. For the root part, $\mathrm{K}$ nutrient concentration highest value was $4.99 \%$ at P5, but were not significantly different with P3 and P4 levels. Likewise, nutrient partitioning result observed similar trend with highest values of $12.2 \%$ for shoot partitioning at $\mathrm{P} 4$.

In $\mathrm{K}_{2} \mathrm{O}$ treatment (Table 6), $\mathrm{N}$ nutrient concentration partitioned in shoot tissues showed higher values of $6.11 \%$ at $\mathrm{K} 2$ and $6.01 \%$ at $\mathrm{K} 3$, with significant different from K1, K4 and K4. Phosphorus nutrient concentration partitioned in shoot tissues was highest value of $1.19 \%$ at K3. For K concentration of nutrient, both the K shoot and root concentration significantly increased with the increased treatment levels up to the highest rate tested with the values of 9.95 and $7.91 \%$ in K5, in the shoot and root, respectively. Similarly, K5 nutrient partitioning significantly gave the highest K5 shoot values of $54.7 \%$ and K5 root of $6.2 \%$, respectively.
According to Peterson's finding, crop plants absorb more $\mathrm{K}_{2} \mathrm{O}$ than any other nutrient except $\mathrm{N}$ (Peterson et al., 2006). For K concentration of nutrient, both $\mathrm{K}$ shoot and root concentration significantly increased with the increased treatment levels indicate potassium is highly mobile within plant. However, $\mathrm{K}$ flow and partitioning can change depending on the forms of $\mathrm{N}$ supply (Zhang et al., 2010). The $\mathrm{NH}_{4}^{+}$nutrition in comparison to $\mathrm{NO}_{3}^{-}$supply results in more $\mathrm{K}$ translocated to leaves. The partitioning of assimilates between roots and shoots is important for the plant growth process. In this nutrient culture experiment, $\mathrm{N}$ and $\mathrm{K}_{2} \mathrm{O}$ nutrition favor an increase in nutrient partitioned in the shoot of oil palm seedlings probably due to increase rate of amino acid translocation to the shoot than the root. However, excessive K may cause $\mathrm{Ca}$ and $\mathrm{Mg}$ deficiencies and nutritional imbalances in the plants, but limited $\mathrm{N}, \mathrm{P}_{2} \mathrm{O}_{5}$ and $\mathrm{K}_{2} \mathrm{O}$ supply on the other hand, decreases rates of cell division, cell expansion, cell permeability, photosynthesis, leaf production, and growth, plants (Roggatz et al., 1999; Reddy et al., 1997).

Among the nutrients, N, P and Kare the major limiting factors in oil palm growth and yield. This study suggested that despite the benefits of these $\mathrm{N}, \mathrm{P}_{2} \mathrm{O}_{5}$ and $\mathrm{K}_{2} \mathrm{O}$ nutrition in oil palm seedlings growth, the correct balance nutrient management levels of each element must be apply to avoid antagonistic interactions that could upset or suppress the uptake of other nutrients and affect the plant growth and development. For optimum crop growth and high yield proper doses of these nutrient elements are required. Responses of oil palm to these $\mathrm{N}, \mathrm{P}_{2} \mathrm{O}_{5}$ and $\mathrm{K}_{2} \mathrm{O}$ nutrition are of considerable importance in agriculture. Therefore, to determine the optimum levels of $\mathrm{N}, \mathrm{P}$ and $\mathrm{K}$ to grow better oil palm seedlings is crucial.

\section{CONCLUSION}

The growth traits, biomass accumulation and partitioning of oil palm seedlings were affected by nutrient uptake and availability. For better nutrient management, based on this study, N, P and K nutrient elements play a critical role in oil palm seedlings growth and development. The fertilization practice is to ensure the growing plant get all the required nutrients for optimum growth. Overall, nutrients uptake in palm tissues ranked in ascending order were as followed: $\mathrm{P}>\mathrm{N}>\mathrm{K}$, respectively. It can be concluded that 100, 90 and $300 \mathrm{mg} \mathrm{L}^{-1}$ of $\mathrm{N}, \mathrm{P}_{2} \mathrm{O}_{5}$, and $\mathrm{K}_{2} \mathrm{O}$, respectively, gave the best growth traits, biomass accumulation and nutrient uptake and were recommended for sustaining optimum and maximum growth of oil palm seedlings. 


\section{ACKNOWLEDGEMENTS}

The authors are extremely grateful to Malaysian Palm Oil Board (MPOB) and Universiti Putra Malaysia (UPM), for jointly funding this research study, and to Universiti Technology MARA (UiTM) for granting study fellowship to the first author. The contribution made by Shamsuddeen Rufai is also acknowledged.

\section{REFERENCES}

Almodares, A., Taheri, R., Chung, I. M., \& Fathi, M. (2008). The effect of nitrogen and potassium fertilizers on growth parameters and carbohydrate contents of sweet sorghum cultivars. Journal of Environmental Biology, 29, 849-852. PMid:19297978.

Bloomfield, K. J., Farquhar, G. D., \& Lloyd, J. (2014). Photosynthesisnitrogen relationships in tropical forest tree species as affected by soil phosphorus availability: a controlled environment study. Functional Plant Biology, 41, 820-832. http://dx.doi.org/10.1071/FP13278.

Cakmak, I., Hengeler, C., \& Marschner, H. (1994). Partitioning of shoot and root dry matter and carbohydrates in bean plants suffering from phosphorus, potassium and magnesium deficiency. Journal of Experimental Botany, 45, 1245-1250. http://dx.doi.org/10.1093/ jxb/45.9.1245.

Conn, S. J., Hocking, B., Dayod, M., Xu, B., Athman, A., Henderson, S., Aukett, L., Conn, V., Shearer, M. K., Fuentes, S., Tyerman, S. D., \& Gilliham, M. (2013). Protocol: optimising hydroponic growth systems for nutritional and physiological analysis of Arabidopsis thaliana and other plants. Plant Methods, 9, 4. http://dx.doi.org/10.1186/17464811-9-4. PMid:23379342.

Corley, R. H. V., \& Tinker, P. B. (2003). The oil palm (4th ed.). Oxford: Blackwell Publishing.. http://dx.doi.org/10.1002/9780470750971.

Fageria, N. K., Baligar, V. C., \& Jones, C. A. (2010). Growth and mineral nutrition of field crops (3rd ed.). New York: CRC Press.. http://dx.doi.org/10.1201/b10160.

Fita, A., Nuez, F., \& Picó, B. (2011). Diversity in root architecture and response to P deficiency in seedlings of Cucumis melo L. Euphytica, 181, 323-339. http://dx.doi.org/10.1007/s10681-011-0432-z.

García-Palacios, P., Maestre, F. T., Bradford, M. A., \& Reynolds, J. F. (2014). Earthworms modify plant biomass and nitrogen capture under conditions of soil nutrient heterogeneity and elevated atmospheric CO2 concentrations. Soil Biology \& Biochemistry, 78, 182-188. http://dx.doi.org/10.1016/j.soilbio.2014.08.002.

Glass, A. D. M. (2003). Nitrogen use efficiency of crop plants: Physiological constraints upon nitrogen absorption. CRC. Critical Reviews in Plant Sciences, 22, 453-470. http://dx.doi.org/10.1080/07352680390243512.
Gupta, P. K. (2007). Soil, plant, water and fertilizer analysis (2nd ed.). India: Agrobios.

Hoagland, D. R, \& Arnon, D. I. (1950). The water culture method for growing plants without soil (Circular 347). Berkeley: California Agricultural Experiment Station, University of California.

Jones, B., Jr. (2003). Agronomic handbook: management of crops, soils, and their fertility. Florida: CRC Press.

Koorem, K., Gazol, A., Öpik, M., Moora, M., Saks, Ü., Uibopuu, A., Sóber, V., \& Zobel, M. (2014). Soil nutrient content influences the abundance of soil microbes but not plant biomass at the smallscale. PLoS One, 9, e91998. http://dx.doi.org/10.1371/journal. pone.0091998. PMid:24637633.

Lawlor, D. W., \& Cornic, G. (2002). Photosynthetic carbon assimilation and associated metabolism in relation to water deficits in higher plants. Plant, Cell \& Environment, 25, 275-294. http:// dx.doi.org/10.1046/j.0016-8025.2001.00814.x. PMid:11841670.

Lobell, D. B. (2007). The cost of uncertainty for nitrogen fertilizer management: a sensitivity analysis. F. Crop. Res, 100, 210-217. http:// dx.doi.org/10.1016/j.fcr.2006.07.007.

Malaysian Palm Oil Board - MPOB. (2013). Oil palm and the environment. Kajang. Retrieved in 15 July 2014, from http://bepi. mpob.gov.my/index.php/statistics/export/121-export-2013.html.

Pardossi, A., Malorgio, F., Incrocci, L., \& Tognoni, F. (2006). Hydroponic technologies for greenhouse crops. In R. Dris (Ed.)., Crops: quality, growth and biotechnology. Helsinky: WFL Publisher.

Parry, M. A. J., Flexas, J., \& Medrano, H. (2005). Prospects for crop production under drought: research priorities and future directions. Annals of Applied Biology, 147, 211-226. http://dx.doi. org/10.1111/j.1744-7348.2005.00032.x.

Peterson, G. A., Unger, W. P., \& Payne, W. A. (2006). Dryland agriculture (2nd ed.). Madison: American Society of Agronomy.

Reddy, K. R., Hodges, H. F., \& Mckinion, J. M. (1997). Modeling temperature effects on cotton internode and leaf growth. Crop Science, 37, 503-509. http://dx.doi.org/10.2135/cropsci1997.001 1183X003700020032x.

Roggatz, U., Mcdonald, A. J. S., Stadenberg, I., \& Schurr, U. (1999). Effects of nitrogen deprivation on cell division and expansion in leaves of Ricinus communis L. Plant, Cell \& Environment, 22, 81-89. http:// dx.doi.org/10.1046/j.1365-3040.1999.00383.x.

Tripler, C. E., Kaushal, S. S., Likens, G. E., \& Walter, M. T. (2006). Patterns in potassium dynamics in forest ecosystems. Ecology Letters, 9, 451-466. http://dx.doi.org/10.1111/j.1461-0248.2006.00891.x. PMid:16623731.

Zhang, F. S., Niu, J., Zhang, W., Chen, X. P., Li, C., Yuan, L., \& Xie, J. C. (2010). Potassium nutrition of crops under varied regimes of nitrogen supply. Plant and Soil, 335, 21-34. http://dx.doi.org/10.1007/ s11104-010-0323-4. 